\title{
PENDEKATAN RESTORATIVE JUSTICE DALAM MELINDUNGI KORBAN KEKERASAN SEKSUAL
}

\author{
Asit Defi Indriyani \\ Divisi Hukum Amita Women Crisis Center Ponorogo \\ asitdefiin04@gmail.com
}

\begin{abstract}
:
The restorative justice approach basically exists to reduce the number of prisoners in prisons. Therefore, as much as possible it is resolved peacefully (mediation) with the aim of restoring the situation to its original state and restoring the pattern of good relations in society. In the case of sexual violence, the loss suffered by the victim is not only physical and material but also psychologically and socially affected. Whether then this Restorative Justice can protect victims and guarantee the rights of victims, of course this is still a big question mark. Physical and material losses may be able to recover in a short time, but psychologically it takes so long even a lifetime. In addition, there is no security guarantee that the perpetrator will not threaten the victim or even repeat his actions when the Restorative Justice process is completed.
\end{abstract}

Keyword: Restorative Justice, sexual violence, victim's right

\begin{abstract}
Abstrak:
Pendekatan keadilan restorative (Restorative Justice) pada dasarnya ada untuk mengurangi jumlah napi dalam lembaga pemasyarakatan. Oleh karena itu sebisa mungkin diselesaikan secara damai (mediasi) dengan tujuan memulihkan keadaan seperti semula dan mengembalikan pola hubungan baik dalam masyarakat. Dalam kasus kekerasan seksual kerugian yang dialami korban tidak hanya fisik dan materil akan tetapi psikis dan sosaialnya juga terdampak. Apakah kemudian Restorative Justice ini bisa melindungi korban serta menjamin hak-hak korban, tentunya hal ini masih menjadi tanda tanya yang besar. Kerugian fisik dan materil mungkin bisa pulih dalam waktu yang singkat, tapi psikis membutuhkan waktu yang begitu panjang bahkan seumur hidup. Selain itu tidak adanya jaminan keamanan bahwa pelaku tidak akan melakukan ancaman terhadap korban atau bahkan mengulangi lagi perbuatannya saat proses Restorative Justice ini selesai..
\end{abstract}

Kata Kunci : Restorative Justice, Kekerasan Seksual, Hak Korban

\section{PENDAHULUAN}

Kekerasan Seksual adalah salah satu dari sekian banyak jenis Kekerasan Berbasis Gender (Gender Based Violence). Kekerasan berbasis gender sendiri adalah kekerasan yang terjadi akibat adanya ketimpangan gender sehingga ada anggapan-anggapan yang mendorong 
seseorang bahwa kekerasan itu pantas dilakukan kepada orang tersebut. Pengertian kekerasan seksual dalam Rancangan Undang-Undang Penghapusan Kekerasan Seksual (RUU PKS) adalah setiap perbuatan merendahkan, menghina, menyerang dan/atau perbuatan lainnya terhadap tubuh, hasrat seksual seseorang dan/atau fungsi reproduksi, secara paksa, bertentangan dengan kehendak seseorang itu tidak mampu memberikan persetujuan dalam keadaan bebas karena ketimpangan relasi kuasa dan/atau relasi gender yang berakibat penderitaan atau kesengsaraan secara fisik, psikis, seksual, kerugian secara ekonomi, sosial, budaya, dan/atau politik. ${ }^{1}$

Data yang tercatat dalam Catatan Tahunan komnas Perempuan (CATAHU ) Komnas Perempuan tahun 2020 menggambarkan bahwa dalam kurun waktu 12 tahun mulai tahun 2008 sampai 2019 kekerasan terhadap perempuan meningkat sebanyak 792\% ( hampir 800\%) artinya kekerasan terhadap perempuan di Indonesia selama 12 tahun meningkat hampir 8 kali lipat. Fenomena ini masih dikatakan seperti gunung es, yang dapat diartikan bahwa dalam situasi yang sebenarnya kondisi perempuan jauh mengalami kehidupan yang tidak aman. ${ }^{2}$

Sedangkan dalam Catatan Tahunan (CATAHU) Komnas Perempuan tahun 2021 bahwa angka kekerasan terhadap perempuan mengalami penurunan sekitar 31,5\% dari tahun sebelumnya. Yang penting menjadi menjadi catatan adalah, penurunan jumlah kasus pada tahun 2020 (299.911 kasus terdiri dari 291.677 kasus di Pengadilan Agama dan 8.234 kasus berasal dari data kuesioner Lembaga pengada layanan) daripada tahun sebelumnya (431.471 kasus - 416.752 kasus di pengadilan agama dan 14.719 data kuesioner), bukan berarti jumlah kasus menurun. Sejalan dengan hasil survei dinamika KtP di masa pandemik penurunan jumlah kasus dikarenakan 1) korban dekat dengan pelaku selama masa pandemik (PSBB); 2) korban cenderung mengadu pada keluarga atau diam;3) persoalan literasi teknologi; 4) model layanan pengaduan yang belum siap dengan kondisi pandemi (belum beradaptasi merubah pengaduan menjadi online). Sebagai contoh karena pandemik, pengadilan agama membatasi layanan nya dan proses persidangan (hal ini menyebabkan angka perceraian turun 125.075 kasus dari tahun lalu). Selain itu turunnya jumlah pengembalian kuesioner hampir 100 persen dari tahun sebelumnya. ${ }^{3}$

\footnotetext{
${ }^{1}$ Draft Rancangan Undang-Undang Penghapusan Kekerasan Seksual (RUU PKS)

${ }^{2}$ Catatan Tahunan (CATAHU) Komnas Perempuan pada tahun 2020

${ }^{3}$ Catatan Tahunan (CATAHU) Komnas Perempuan tahun 2021
} 
Kekerasan Seksual mengakibatkan korban mengalami kerugian materi, fisik dan juga psikisnya Seringkali dalam penyelesaiannya masyarakat masih banyak yang menganggap remeh. Ada yang menyelesaikannya dengan cara pelaku membayar ganti rugi dengan uang, ada yang menikahkan korban dengan pelaku, bahkan ada yang dengan cara pelaku membayar denda kepada lingkungan masyarakat seperti mengaspal jalan dan lain-lain. Padahal itu sama sekali tidak bisa mengembalikan korban ke keadaan semula. Trauma yang dialami sangat membutuhkan waktu yang sangat panjang, apalagi dengan menikahkan dengan pelaku, korban akan hidup dengan pelaku seumur hidup dan masih ada potensi pelaku akan melakukan kekerasan lagi terhadap korban

Kekerasan seksual di dalam hukum positif harini dapat dijerat dengan beberapa pasal yaitu Undang-Undang No 23 Thun 2004 tentang Penghapusan Kekerasan Dalam Rumah Tangga, Undang-Undang No 23 Tahun 2002 tentang Perlindungan Anak, pasal 284-290 KUHP dan lainlain. Meskipun begitu masih banyak jenis kekerasan seksual yang tidak bisa dijerat hukum karena belum adanya regulasi atau undang-undang yang mengakomodir jenis kekerasan tersebut.

Di dalam sistem hukum pidana kita hari ini dalam hal penyelesaian tindak pidana lebih mengutamakan pendekatan restorative justice. Sesuai dengan surat keputusan yang dikeluarkan oleh Mahkamah Agung Nomor 1691/DJU/SK/ PS.00/12/2020 tentang Pemberlakuan Pedoman Penerapan Keadilan Restoratif (Restorative Justice). Pendekatan restorative justice sendiri adalah sebuah alternative penyelesaian perkara pidana dengan mediasi mempertemukan korban dan pelaku beserta pihak keluarga dengan berfokus pada pengembalian ke keadaan semula baik pelaku maupun korban.

Tindak pidana menurut kaca mata keadilan restoratif, adalah suatu pelanggaran terhadap manusia dan relasi antar manusia. Keadilan restoratif, dapat dilaksanakan melalui: Mediasi korban dengan pelanggar; Musyawarah kelompok keluarga; pelayanan di masyarakat yang bersifat pemulihan baik bagi korban maupun pelaku. Penerapan prinsip keadilan tindak pidana menurut kaca mata keadilan restoratif, adalah suatu pelanggaran terhadap manusia dan relasi antar manusia. Keadilan restoratif, dapat dilaksanakan melalui: Mediasi korban dengan 
pelanggar; Musyawarah kelompok keluarga; pelayanan di masyarakat yang bersifat pemulihan baik bagi korban maupun pelaku. ${ }^{4}$

Keadilan restorative memang memiliki tujuan yang sangat baik yaitu kembalinya kondisi semula setelah terjadinya tindak pidana. Tapi apakah kemudian ini bisa menjamin dapat menghadirkan rasa kedilan bagi korban kekerasan seksual mengingat begitu banyaknya kerugian dan proses penyembuhan trauma yang begitu panjang bahkan seumur hidup. Selain itu kekerasan seksual memiliki kekhususan penanganan di banding tindak pidana yang lain.

Dari berbagai dilematis dan permasalahan inilah penulis akan mengulas tentang pendekatan restorative justice dalam melindungi korban kekerasan seksual. Tujuan dari tulisan ini adalah untuk menelaah dan merefleksikan kembali pendekatan restorative justice dalam penanganan kasus kekerasan seksual dalam perspektif korban. Agar pilihan metode penanganan tindak pidana kekerasan seksual benar-benar dapat memberikan rasa keadilan bagi korban khususnya sehingga dapat memulihkan korban dalam keadaan semula serta terlindungi dari berbagai ancaman dan potensi pengulangan kekerasan.

\section{PEMBAHASAN}

\section{Konsep Restorative Justice}

Restorative Justice atau sering diterjemahkan sebagai keadilan restorasi, merupakan suatu model pendekatan yang muncul dalam era tahun 1960-an dalam upaya penyelesaian perkara pidana. Berbeda dengan pendekatan yang dipakai pada sistem peradilsan pidana konvensional, pendekatan ini menitikberatkan adanya partisipasi langsung dari pelaku, korban dan masyarakat dalam proses penyelesaian perkara pidana. ${ }^{5}$

Prinsip keadilan restorative adalah (Restorative Justice) adalah salah satu prinsip penegakan hukum dalam penyelesaian perkara yang dapat dijadikan instrument pemulihan dan sudah dilaksanakan oleh Mahkamah Agung dalam bentuk pemberlakuan kebijakan (Peraturan

\footnotetext{
${ }^{4}$ Hanafi Arief, Ningrum Ambarsari, Penerapan Prinsip Restorative justice dalam Sistem Peradilan Pidana di Indonesia, Jurnal Al Adl, Vol. 10, No 2, Juli 2018, hal 18

${ }^{5}$ Yusi Amdani, Konsep Restorative Justice dalam Penyelesaian Perkara Tindak Pidana Pencurian oleh Anak Berbasis Hukum Islam dan Adat Aceh, Jurnal Al-Adalah Vol. XII, No 1, Juni 2016, hal 64
} 
Mahkamah Agung dan Surat Edaran Mahkamah Agung), namun pelaksanaannya dalam sistem peradilan pidana Indonesia masih belum optimal. 6

Keadilan Restorative Justice merupakan alternative penyelesaian perkara tindak pidana yang dalam mekanisme tata cara peradilan pidana berfokus pada pemidanaan yang diubah menjadi proses dialog dan mediasi yang melibatkan pelaku, korban, keluarga pelaku/korban, dan pihak lain yang terkait untuk bersama-sama menciptakan kesepakatan atau penyelesaian perkara pidana yang adil dan seimbang bagi pihak korban maupun pelaku dengan mengedepankan pemulihan kembali pada keadaan semula, dan mengembalikan pola hubungan baik dalam masyarakat. Prinsip dasar keadilan restorative (restorative justice) adalah pemulihan kepada koeban yang menderita akibat kejahatan dengan memberikan ganti rugi kepada korban, perdamaian, pelaku melakukan kerja sosial maupun kesepakatan-kesepakatan lainnya. Hukum yang adil di dalam keadilan restorative tentunya tidak berat sebelah, tidak memihak, tidak sewenang-wenang dan hanya berpihak pada kebenaran sesuai aturan perundang-undangan yang berlaku serta mempertimbangkan kesetaraan hak kompensasi dan keseimbangan dalam setiap aspek kehidupan. Pelaku memiliki kesempatan terlibat dalam pemulihan keadaan (restorasi), masyarakat berperan untuk melestarikan perdamaian, dan pengadilan berperan untuk menjaga ketertiban umum. ${ }^{7}$

Liebmann secara sederhana mengartikan restorative justice sebagai suatu sistem hukum yang bertujuan untuk mengembalikan kesejahteraan korban, pelaku dan masyarakat yang rusak oleh kejahatan, dan untuk mencegah pelanggaran atau tindakan kejahatan lebih lanjut. Liebman juga memberikan rumusan prinsip dasar restorative justice sebagai berikut:

a. Memprioritaskan dukungan dan penyembuhan korban.

b. Pelaku pelanggaran bertanggungjawab atas apa yang mereka lakukan.

c. Dialog antara korban dengan pelaku untuk mencapai pemahaman.

d. Ada upaya untuk meletakkan secara benar kerugian yang ditimbulkan.

\footnotetext{
${ }^{6}$ Ibid

${ }^{7}$ Surat Keputusan Mahkamah Agung Nomor 1691/DJU/SK/PS.00/12/2020 tentang Pemberlakuan Pedoman Penerapan Keadilan Restoratif (Restorative Justice, hal 2-3
} 
e. Pelaku pelanggar harus sadar tentang bagaimana cara menghindari kejahatan di masa depan.

f. Masyarakat turut membantu dalam mengintegrasikan dua belah pihak, baik korban maupun pelaku. ${ }^{8}$

\section{Kekerasan Seksual dan Hak Korban}

Kekerasan atau violence merupakan istilah yang terdiri dari dua kata, yaitu "vis" yang berarti (daya, kekuatan) dan "latus" berarti (membawa), yang kemudian diterjemahkan sebagai membawa kekuatan. Kamus Besar Bahasa Indonesia memberikan pengertian mengenai kekerasan dalam arti sempit yaitu hanya mencakup kekerasan fisik. Menurut KBBI Kekerasan adalah perbuatan yang dapat menyebabkan cidera atau matinya orang lain atau menyebabkan kerusakan fisik atau barang orang lain. ${ }^{9}$

Kekerasan seksual sendiri merupakan suatu tindakan seksual secara fisik maupun non fisik oleh seseorang yang memiliki kekuasaan atas korban dengan tujuan memenuhi hasrat seksual pelaku yang tidak dikehendaki oleh korban. Menurut Komisi Nasional Anti kekerasan terhadap Perempuan (Komnas Perempuan), terdapat konsep moralitas terkait perempuan yang berkembang di tengah masyarakat. Perempuan dianggap sebagai simbol kesucian dan kehormatan. Konsep ini membuat perempuan seringkali dipandang sebagai aib kala mengalami tindak kekerasan seksual. Tidak hanya itu, perempuan pun sering menjadi pihak yang disalahkan atas tindakan tersebut. Hal ini pun, menjadi alasan banyak perempuan di Indonesia yang mengalami kekerasan seksual memilih bungkam. ${ }^{10}$

Pengertian kekerasan seksual dalam Rancangan Undang-Undang Penghapusan Kekerasan Seksual (RUU PKS) adalah setiap perbuatan merendahkan, menghina, menyerang dan/atau perbuatan lainnya terhadap tubuh, hasrat seksual seseorang dan/atau fungsi reproduksi, secara paksa, bertentangan dengan kehendak seseorang itu tidak mampu

\footnotetext{
${ }^{8}$ Marian Liebmann, Restorative Justice, How it Work (London and Philadelpia: Jessica Kingsley Publishers, 2007), hl 26

${ }^{9}$ Maulida H.Syaiful Tency dan Ibnu Elmi, Kekerasan Seksual dan Perceraian, Intimedia, Malang, 2009, Hlm 17

10 Hadibah Zachra Wadjo dan Judy Marria Saimima, Perlindungan Hukum Terhadap Korban Kekerasan Seksual Dalam Rangka Mewujudkan Keadilan Restoratif, jurnal Belo, Vol. 6, No 1, Januari 2021, hlm 49
} 
memberikan persetujuan dalam keadaan bebas karena ketimpangan relasi kuasa dan/atau relasi gender yang berakibat penderitaan atau kesengsaraan secara fisik, psikis, seksual, kerugian secara ekonomi, sosial, budaya, dan/atau politik. ${ }^{11}$ Bentuk-bentuk Kekerasan seksual dalam RUU PKS sendiri antara lain:

1. Pelecehan seksual

2. Eksploitasi seksual

3. Pemaksaan kontrasepsi

4. Pemaksaan aborsi

5. Perkosaan

6. Pemaksaan perkawinan

7. Pemaksaan pelacuran

8. Perbudakan seksual dan

9. Penyiksaan seksual

Korban biasanya mengalami penderitaan baik fisik, psikis, maupun ekonomi bahkan sosial yang diakibatkan oleh suatu perbuatan. Definisi korban sendiri dalam Undang-undang No 13 Tahun 2006 tentang Perlindungan Saksi dan Korban adalah orang yang mengalami penderitaan fisik, mental dan/atau kerugian ekonomi yang diakibatkan oleh suatu tindak pidana.

Dalam Undang-undang No 13 Tahun 2006 tentang Perlindungan Saksi dan Korban pasal 5 disebutkan bahwa korban berhak atas:

1. Memperoleh perlindungan atas keamanan pribadi, keluarga dan harta bendanya, serta bebas dari ancaman yang berekenaan dengan kesaksian yang akan, sedang, atau telah diberikannya

2. Ikut serta dalam proses memilih dan menentukan bentuk perlindungan dan dukungan keamanan

3. Memberikan keterangan tanpa tekanan

4. Mendapat penerjemah

5. Bebas dari pertanyaan yang menjerat

${ }^{11}$ Draft Rancangan Undang-Undang Penghapusan Kekerasan Seksual (RUU PKS) 
6. Mendapatkan informasi mengenai perkembangan kasus

7. Mendapatkan informasi mengenai putusan pengadilan

8. Mengetahui dalam hal terpidana dibebaskan

9. Mendapat identitas baru

10. Mendapatkan tempat kediaman baru

11. Memperoleh penggantian biaya transportasi sesuai dengan kebutuhan

12. Mendapat nasihat hukum dan/atau

13. Memperoleh bantuan biaya hidup sementara sampai batas waktu perlindungan berakhir ${ }^{12}$

Sedangkan hak -hak korban yang terdapat dalam Rancangan Undang-Undang Penghapusan Kekerasan Seksual (RUU PKS) antara lain adalah:

1. Hak atas penanganan yang bertujuan memberikan pelayanan terpadu yang multisektor dan terkoordinasi kepada korban dan mendukung korban menjalani proses peradilan pidana

2. Hak atas perlindungan yang bertujuan memberikan rasa aman dan keamanan bagi korban, keluarga korban, dan harta bendanya selama dan setelah proses peradilan pidana kekerasan seksual

3. Hak atas pemulihan yang bertujuan untuk memulihkan, menguatkan dan memberdayakan korban dan keluarga korban dalam mengambil keputusan terhadap kehidupannya selama dan setelah proses peradilan agar lebih adil, bermartabat dan sejahtera ${ }^{13}$

Meskipun dalam Undang-Undang No 13 Tahun 2006 tentang Perlindungan Saksi dan Korban telah menjamin rasa aman dalam memberikan keterangan dalam proses pemeriksaan. Perwujudan rasa aman yang sering tidak berjalan sesuai dengan tujuan dari peraturan perundang-undangan tersebut membuat korban cenderung lebih memilih untuk diam. ${ }^{14}$

Ketika korban mencoba untuk berbicara seringkali mereka berfikir bahwa tidak ada satupun orang yang akan percaya dan berpihak kepadanya. Sehingga pada akhirnya korban

\footnotetext{
${ }^{12}$ Undang-undang No 13 Tahun 2006 tentang Perlindungan Saksi dan Korban

${ }^{13}$ Lucky Endrawati, dalam Dialog publik RUU PKS, Aula FUAD Kampus 2 IAIN Ponorogo, 20 Maret 2019

${ }^{14}$ Maria Novita Apriyani, Implementasi Restitusi Bagi korban Tindak Pidana Kekerasan Seksual, Jurnal Risalah Hukum, Vol. 17, No. 1, Juni 2021, Hlm 3
} 
memilih untuk diam. Dalam kondisi seperti ini kehadiran pendamping menjadi sangat penting, baik pendamping hukum maupun pendamping psikisnya (psikolog).

\section{Pendekatan Restorative Justice dalam Melindungi Korban Kekerasan Seksual}

Restorative justice sebenarnya sudah bukan hal yang asing lagi dalam peradilan pidana di Indonesia. Sistem ini telah dikenal dalam Undang-Undang Sistem Peradilan Pidana Anak yang lebih dikenal dengan kata "diversi" atau pengalihan. Pada prinsipnya adalah sama seperti restorative justice. Akan tetapi diversi ini harus dilakukan atau bersifat wajib pada penanganan kasus anak berhadapan dengan hukum. Sedangkan dalam kasus lain termasuk kasus kekerasan seksual sifatnya adalah lebih kepada anjuran. Semenjak dikeluarkannya Surat Keputusan Mahkamah Agung Nomor 1691/DJU/SK/PS.00/12/2020 tentang Pemberlakuan Pedoman Penerapan Keadilan Restoratif (Restorative Justice) pendekatan ini diberlakukan dengan memperhatikan hal-hal penting yang ada dalam pedoman.

Di dalam Surat Keputusan Mahkamah Agung Nomor 1691/DJU/SK/ PS.00/12/2020 tentang Pemberlakuan Pedoman Penerapan Keadilan Restoratif (Restorative Justice) dijelaskan bahwa dalam mengadili kasus perempuan berhadapan dengan hukum harus memperhatikan riwayat kekerasan dari pelaku terhadap korban, relasi kuasa yang mengakibatkan korban tidak berdaya, ketidakberdayaan psikis dan fisik korban, dampak psikis yang dialami korban, diskriminasi,ketidaksetaraan perlindungan hukum yang berdampak pada akses keadilan dan ketidaksetaraan status sosial antara para pihak yang berperkara.

Kekerasan seksual menimbulkan banyak akibat negatif apalagi jika korbannya adalah anak yang masih membutuhkan waktu untuk bertumbuh dan berkembang. Tindak kekerasan tersebut pasti akan sangat membekas dan meninggalkan efek yang lama baik secara fisik maupun secara mental. Bentuk-bentuk kekerasan seksual umumnya dilakukan dengan upaya memaksa dan keinginan salah satu pihak saja untuk merayu, mencolek, memeluk, meremas bagian tubuh, dan segala macam bentuk pelecehan lainnya hingga tujuan utamanya melakukan persetubuhan secara paksa. Kekerasan seksual dapat terjadi karena beberapa hal, mulai dari pola pengasuhan keluarga yang keliru, penyebaran pornografi di sosial media yang tidak terkontrol, hingga tidak 
adanya pendidikan seksual yang benar sejak dini. Hal ini membuat anak menjadi tidak mampu menyaring informasi yang seharusnya didapati sehingga anak cenderung berbuat salah. ${ }^{15}$

Perhatian kepada pemulihan korban kekerasan seksual dan pemidanaan bagi pelakunya perlu sebanding dengan perhatian kita untuk mencegah peristiwa berulang. Tindakan yang diterima oleh korban bisa mengubah hidupnya secara drastis dengan berbagai dampak yang dialami antara lain stress yang berujung depresi, trauma, dan penyakit-penyakit lainnya hingga korban dapat mengakhiri hidupnya sendiri ${ }^{16}$

Korban kekerasan seksual mengalami kerugian yang begitu banyak sehingga perlu kiranya mendapatkan perlindungan yang sepadan. Kerugian yang dialami korban bisa dikatakan beruntun yaitu mulai kerugian fisik, psikis dan juga sosialnya. Seain itu korban juga pada saat pra persidangan, selama proses persidangan hingga setelah persidangan selesai. Oleh karena itu korban kekerasan seksual membutuhkan perlindungan agar mendapatkan rasa aman dan nyaman dari segala bentuk ancaman serta potensi pengulangan kekerasan dan korban terjamin proses pemulihannya

Menurut penulis, pendekatan restorative justice tidak bisa dijadikan sebagai jalan keluar penyelesaian kasus kekerasan seksual karena selain kurang bisa melindungi korban, ini akan mengakibatkan munculnya pemikiran atau anggapan bahwa apa yang dilakukan pelaku bisa diselesaikan dengan hanya ganti rugi dan pelaku kembali bebas berkeliaran dimana saja. Selain itu tidak ada jaminan keamanan bagi korban jika ada ancaman dari pelaku. Kebanyakan pelaku kekerasan seksual adalah orang terdekat korban bahkan keluarganya sendiri. Sesuai dalam Catatan Tahunan (CATAHU) Komnas Perempuan tahun 2021 bahwa dalam ranah personal pelaku kekerasan seksual terbanyak adalah pacar sebanyak 1074 kasus dan konsisten sejak 3 tahun lalu. Selain pacar sebagai pelaku kekerasan seksual ayah kandung sebagai pelaku kekerasan seksual sebanyak 165. ${ }^{17}$ Maka ketika pelaku sudah membayar ganti rugi dan bebas tentunya hal ini akan berpotensi bahwa korban akan mengalami kekerasan yang berulang oleh pelaku.

\footnotetext{
${ }^{15}$ Hadibah Zachra Wadjo dan Judy Marria Saimima, hlm 51

${ }^{16}$ Mawati, E., Takariawan, A., \& Sulistiani, L. (2020). Kebijakan Hukum Pidana Mengenai Rehabilitasi Psikososial Korban Tindak Pidana Terorisme Dalam Sistem Peradilan Pidana. Jurnal Belo , 5 (2), $34-56$

${ }^{17}$ Catatan Tahunan (CATAHU) Komnas Perempuan tahun 2021 hlm 18
} 
Pendekatan restorative justice ini dapat dijadikan pendekatan penyelesaian kasus kekerasan hanya jika pelaku adalah seorang anak, karena anak sebagai pelaku disini sejatinya juga adalah korban dari lingkungannya yang membentuk perilakunya. Selain itu karena anak belum bisa berfikir jenih mana yang boleh dilakukan dan mana yang tidak boleh dilakukan. Hal ini sesuai dengan amanah undang-undang khusus peradilan anak.

Komnas perempuan juga memiliki pandangan terkait restorative justice dalam penanganan kasus kekerasan seperti pada kutipan pernyataan sikapnya dalam menanggapi Kemenkopolhukam pada Februari 2021 lau seperti dibawah ini:

"Mengingat beragam praktik atas nama Restorative Justice dapat menempatkan perempuan korban kekerasan terpuruk dalam ketidakadilan berlapis, Komnas Perempuan mengajak Kemenkopolhukam dan semua pihak untuk terus melakukan pengawasan pada pelaksanaan Restorative Justice, baik yang diselenggarakan melalui institusi penegak hukum maupun yang ada di tengah-tengah masyarakat. Juga, untuk bersama-sama melakukan kajian yang lebih menyeluruh tentang Restorative Justice, termasuk menyangkut upaya spenanganan pelanggaran HAM masa lalu, untuk menguatkan konsep, kebijakan dan pedoman pelaksanaannya. Penguatan ini dibutuhkan agar dalam kerangka Restorative Justice, selain membangun keharmonisan warga, juga mengutamakan pemenuhan hak korban, khususnya perempuan korban kekerasan, atas kebenaran, keadilan dan pemulihan."18

Penulis sepakat dengan apa yang dikatakan oleh komnas perempuan dalam pernyataan sikapnya saat menanggapi menkopolhukam tersebut, bahwa restorative justice hendaknya terus dikuatkan konsepnya agar lebih mengutamakan pemenuhan hak-hak korban kekerasan serta haknya untuk dapat pulih kembali dari trauma dan keadaan sosialnya. Kepentingan bagi korban adalah menjadi suatu hal paling penting dari segala hal. Kalaupun pendekatan restorative justice ini dipakai hendaknya berdasarkan persetujuan korban, bukan berarti kemudian menjadi satusatunya pilihan jalan penyelesaian.

\footnotetext{
${ }^{18}$ Pernyataan Sikap Komnas Perempuan pada Pemberitaan Pernyataan Menkopolhukam tentang Restorative Justice (20 Februari 2021)
} 


\section{PENUTUPAN}

Berdasarkan pembahasan diatas dapat ditarik kesimpulan bahwa kekerasan seksual merupakan tindak pidana yang dapat menimbulkan banyak dampak negatif bagi korban. Selain korban mengalami penderitaan dan kerugian fisik, materil dan sosialnya, korban juga mengalami penderitaan psikis yang pemulihannya membutuhkan waktu yang cukup lama bahkan seumur hidup. Korban juga masih harus menanggung beban stigma negative yang diberikan masyarakat kepada korban. Pendekatan restorative justice tidak bisa dijadikan sebagai jalan keluar penyelesaian kasus kekerasan seksual karena selain kurang bisa melindungi korban, ini akan mengakibatkan munculnya pemikiran atau anggapan bahwa apa yang dilakukan pelaku bisa diselesaikan dengan hanya ganti rugi dan pelaku kembali bebas berkeliaran dimana saja. Selain itu tidak ada jaminan keamanan bagi korban jika ada ancaman dari pelaku. Restorative justice hendaknya terus dikuatkan konsepnya agar lebih mengutamakan pemenuhan hak-hak korban kekerasan serta mendapatkan haknya untuk pulih kembali dari trauma dan keadaan sosialnya. Karena kepentingan bagi korban adalah menjadi suatu hal paling penting dari segala hal.

\section{DAFTAR RUJUKAN}

Amdani, Yusi Konsep Restorative Justice dalam Penyelesaian Perkara Tindak Pidana Pencurian oleh Anak Berbasis Hukum Islam dan Adat Aceh, Jurnal Al-Adalah Vol. XII, No 1, Juni 2016

Arief, Hanafi, Ningrum Ambarsari, Penerapan Prinsip Restorative justice dalam Sistem Peradilan Pidana di Indonesia, Jurnal Al Adl, Vol. 10, No 2, Juli 2018

Catatan Tahunan (CATAHU) Komnas Perempuan tahun 2020

Catatan Tahunan (CATAHU) Komnas Perempuan tahun 2021

Draft Pernyataan Sikap Komnas Perempuan pada Pemberitaan Pernyataan Menkopolhukam tentang Restorative Justice (20 Februari 2021)

Draft Rancangan Undang-Undang Penghapusan Kekerasan Seksual (RUU PKS)

Endrawati, Lucky, naskah materi dalam Dialog publik RUU PKS, Aula FUAD Kampus 2 IAIN Ponorogo, 20 Maret 2019

Liebmann, Marian Restorative Justice, How it Work (London and Philadelpia: Jessica Kingsley Publishers, 2007) 
Mawati, E., Takariawan, A., dan Sulistiani, L. . Kebijakan Hukum Pidana Mengenai Rehabilitasi Psikososial Korban Tindak Pidana Terorisme Dalam Sistem Peradilan Pidana. Jurnal Belo, Vol. 5 No. 2

Novita Apriyani, Maria Implementasi Restitusi Bagi korban Tindak Pidana Kekerasan Seksual, Jurnal Risalah Hukum, Vosl. 17, No. 1, Juni 2021

Surat Keputusan Mahkamah Agung Nomor 1691/DJU/SK/PS.00/12/2020 tentang Pemberlakuan Pedoman Penerapan Keadilan Restoratif (Restorative Justice

Syaiful Tency, Maulida dan Ibnu Elmi, Kekerasan Seksual dan Perceraian, Intimedia, Malang, 2009,

Undang-undang No 13 Tahun 2006 tentang Perlindungan Saksi dan Korban

Zachra Wadjo, Hadibah dan Judy Marria Saimima, Perlindungan Hukum Terhadap Korban Kekerasan Seksual Dalam Rangka Mewujudkan Keadilan Restoratif, jurnal Belo, Vol. 6, No 1, Januari 2021 